
PPeriodica Polytechnica
Architecture

47(1), pp. 1-7, 2016

DOI: 10.3311/PPar.9261

Creative Commons Attribution (i)

RESEARCH ARTICLE

\section{When a Good Solution Becomes the New Problematic: Building Solutions from the 1980s Are an Issue of Today's Renovations}

\author{
Andreja Benko ${ }^{1 *}$
}

Received 30 March 2016; accepted after revision 04 May 2016

\begin{abstract}
In Slovenia today, architects have to deal with numerous renovations of former architectural practice in Yugoslavia. Until 1991, Slovenia belonged to the former Republic of Yugoslavia for more than 50 years. Following World War 2, most countries in Europe had to deal with major housing problems and Yugoslavia was no exception. Yugoslavia dealt with these problems from two directions, either by building special neighbourhoods or by investing in its real estate in the form of single-family houses.
\end{abstract}

This "mass housing" approach also occurred in Slovenia. Most houses were built between 1970 and 1980. These structures were typically built by the owners themselves with the help of friends and relatives, although professional architects still provided the designs. They were planned with all the legal documentation but with no special interest or architectural inspiration.

The article deals with the exposed problematic and offers some solutions for the future. Its aim is to raise awareness of architects' work with the broader public, who are in most cases investors of architectural documentation. The article also deals with the problematic of responsibility when dealing with space interventions.

\section{Keywords}

mass housing, Slovenia, socialistic architecture, architectural design

\section{Introduction}

The Republic of Slovenia has been an independent country since 1991 and is divided into seven main regions (Fig. 1). In the past, the Republic of Slovenia or some parts of it belonged to several countries and regimes (Fig. 2). Between 1867 and 1918, it was part of the Austro-Hungarian monarchy, after that, Republic SHS, Yugoslavian kingdom, and from 1945 until 1991 was an important part of the Socialist Federal Republic of Yugoslavia (SFRY). Each period left significant impacts on the territory of Slovenia in the built environment according to legalisation valid at the time of the affiliation. The most important is the period after World War 2 (WW2), as the buildings built at that time are still mostly present today and suitable for reconstruction.

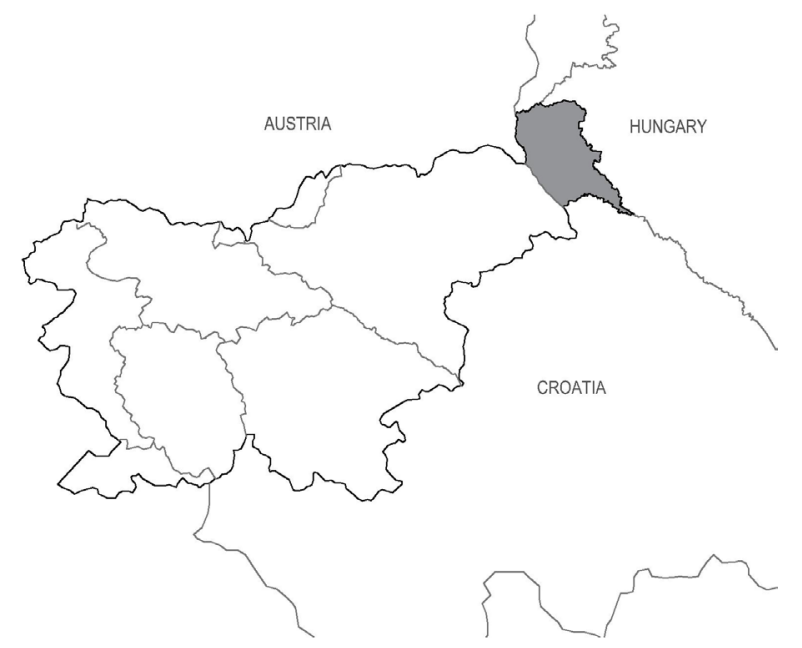

Fig. 1 Slovenia and its regions. The figure shows the region of Prekmurje (in grey), where the exposed problematic in the article is most visible and largely present (author: Andreja Benko)

For this reason, the article focuses on the period of mass residential construction that dominated in the years after WW2. During this time, the area of Slovenia belonged to SFRY and this approach was an option for solving the residential problem. This methodology for solving the residential building issue was typical not only for Slovenia but the whole area of the former SFRY.

\footnotetext{
${ }^{1}$ Faculty of Architecture, University of Ljubljana, Zoisova 12, 10000 Ljubljana

*Corresponding author, e-mail: Andreja.benko@fa.uni-lj.si
} 
From the urban perspective and the built interaction with the architectural landscape, there were two types of buildings:

- Apartment blocks, which are problematic because of the high density of construction, high percentage of plot use and poor integration of buildings into the architectural landscape.

- Individual single family housing of that time, which are challenging due to the discordant plans used for their realization.

\section{Problematics}

The consequences of previous architectural and constructional solutions are often visible later when they show the mistakes of architectural planning and construction. Often they are unintentional and represented at that time the optimal solution. It is important for the profession to learn from past mistakes, and not to repeat them. Space planning (urban planning) should manage space usage in the future. This definition seems to be obvious and generally accepted. However, professional discussion often forgets about time as an important extension of planning (Kos, 2002).

The main focus of the article is on single-family houses of that time; hence, the analysis exposes the next two important problematics from that field:

- Single family house design that represents the period of mass housing

- Illegal and discordant single family houses as a consequence of mass housing.

The exposed problematic is supplemented with a discussion on the role and position of the architect, based upon the exposed problematic.

\section{Methodology}

The theme was treated and analysed from a historical and critical point of view using a multimethod approach. For the theme, historical, analytical and descriptive methods were used, which are complimentary.

The historical method is used at the beginning of the article, where we describe the situation in the past and expose the terms and conditions that led to the current problems. With the analytical method, we examine the current situation. From the analyses and synthesis, guidelines for solving problems have been suggested. The descriptive method complements the previously mentioned methods and is used for describing the situation and providing solutions.

The research area is focused on the Republic of Slovenia, for which based on analyses and exposed problems, possible solutions were given.

\section{Research}

\subsection{Historical background}

Some solutions carried out under previous systems we nowadays see as problems. In this way, we can also see the "solution" to the post-war housing problem. To understand the background, we have to look 60 (or more) years back to comprehend the idea that led to the solutions at that time.

WW2 affected many people, even worse was the period right after the war; the triumphal period was also a period of major shortages. One of the main problems for survivors besides the loss of relatives was the problem of lost property and accommodation. Many of the survivors, already middleaged, had to start over again. The development of Slovenian towns after 1945 was affected by the two main forms of residential construction. One known as "social construction" of residential neighbourhoods of blocks of flats, the second the "individual" construction of single-family houses (Rebernik, 2002). This decisively affected urbanism and spatial planning in the Slovenian territory, Fig. 2. Hungary also had the same issues, although they took a different approach. Socialist Hungary was unusual in leaving most homes in private ownership after 1948, and much of the apartment block housing constructed by the socialist state after the 1960s was owneroccupied from the start; what remained of state-owned housing was quickly privatized in 1991-92 (Fehérváry, 2011).
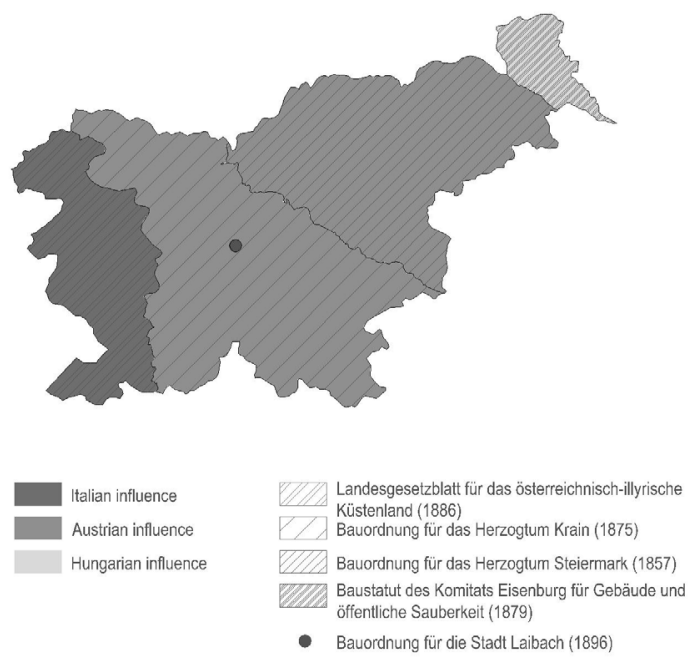

Fig. 2 The scope of the $19^{\text {th }}$ Century building codes in the area of Slovenia. The figure also shows the position of Prekmurje. Until 1919, only Prekmurje belonged to the Hungarian part of the Austro-Hungarian monarchy (Author: Andreja Benko).

\subsection{House construction as an investment opportunity}

Historical sources of the SFRY also describe property nationalisation, the so-called common ownership. This was solved in the 1990s when nationalized property was denationalized and returned to beneficiaries. Nationalisation was important to 
cover the need for housing immediately after WW2; although, these buildings could not provide enough homes for all that needed them. This launched the political decision about mass construction. The strategy of the country was to provide a home for every inhabitant. The state planned designed and constructed neighbourhoods of blocks, especially in the bigger more important cities, (for example, Ljubljana, Maribor Velenje, Jesenice and also in Murska Sobota - a large city in the region of Prekmurje) (Fig. 3); however, they did not meet all the demand. Also, the financial level/social standard required to get an apartment in a block built by state was particularly hard. Consequently, the SFRY allowed the optional investment of building a single family house on private land (by themselves and with the help of friends) (Brezar, 1999).

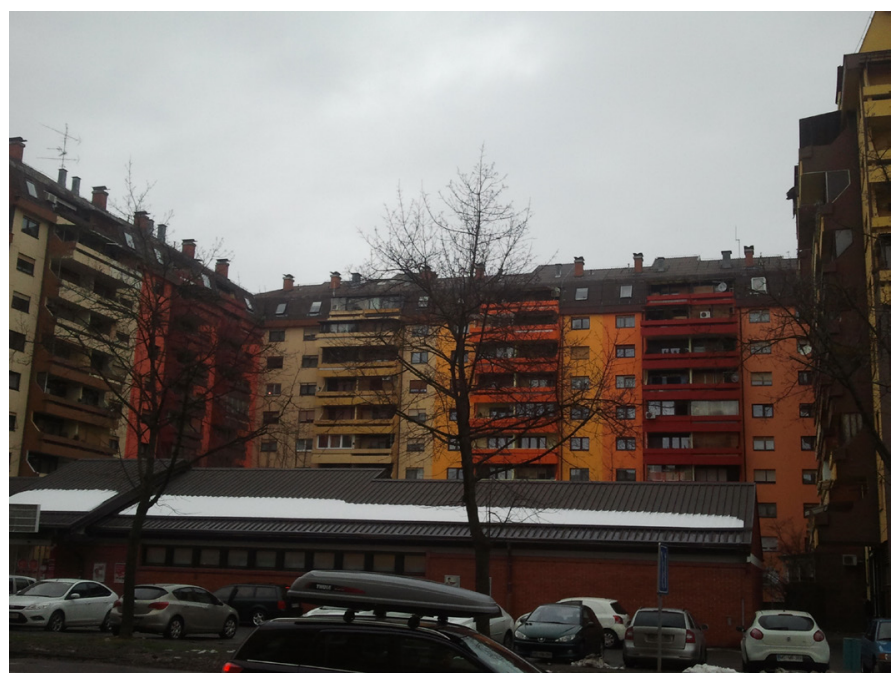

Fig. 3 An example of the popular blocks of flats built in Murska Sobota in the discussed period. The current restoration-façade illustrates the issue of communication between neighbours (Author: Andreja Benko).

This type of construction was the most common in the small, more rurally oriented towns and suburban towns. This "solution" led to the expansion of "type construction", that reached its peak in the 1970s. The idea of an owned house with a small garden was very popular at the time of the SFRY. An example of this was a house in the countryside.

This idea comes from the "workers' neighbourhoods" that were built between 1850 and 1950. An example of this is the workers' neighbourhood in Maribor built by "Southern Railways (Südbanh)". The household consisted of an orchard, woodshed, and stables with covered entrance, a small vegetable garden, flower bed and a small flat in the terraced building. We can find similar concepts of workers' neighbourhoods all over Europe as these were created in a period of development that was significant for the European continent (Schwertner et al., 2011).

The Slovenian investor is traditional about the house and also in the choice of material (Brojan, 2014). Some chosen materials used at that time (for example Salonit with asbestos) are today known as dangerous to human health. However, asbestos was at that time a common material that everyone could afford and with that solve the problem of a home.

The construction of single-family houses, even today, based on analysis (STAT, 2015) represents the most common type of construction in Slovenia, Fig. 4. This parallels the residential construction in the Hungarian Republic, confirmed by Fehérváry (2011): ... of the many transformations to the Hungarian landscape after the fall of state socialism, one of the most striking was the emergence of small "suburbanized" neighbourhoods of detached family houses.

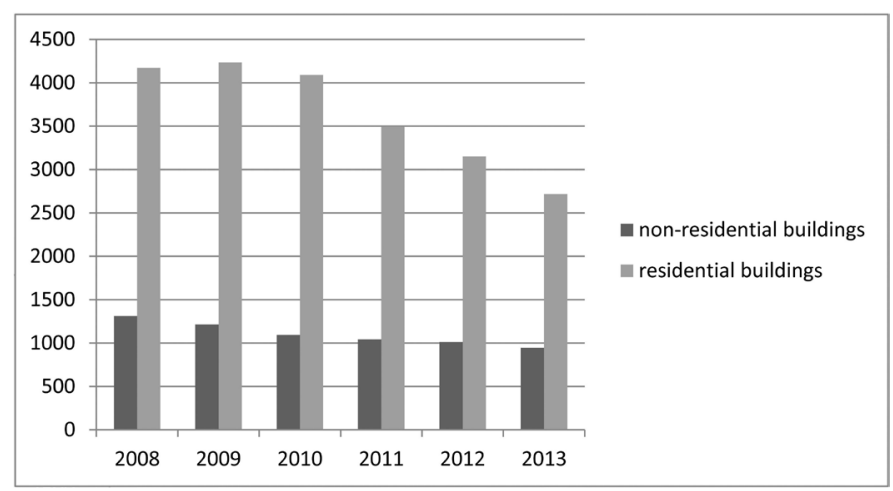

Fig. 4 Tabular presentation of completed buildings in Slovenia by year, separated into residential buildings and non-residential buildings, after STAT (author: Andreja Benko).

\subsection{The period of self-managed construction}

In the period examined, the inhabitants of SFRY massively built new homes, in most cases big enough for two families. Today, these buildings are typically at least 50 percent used and at the same time have high energy consumption. The users often cannot manage energetic restoration because of their age, income, and inappropriate energetic subsidies, although it is both essential and necessary. The majority of these houses were designed by professionals, but without knowing the real users; consequently, they were impersonal designs. In most cases, architects only redrew type plans, which were also cheaper. The discussed objects were designed in architectural studios but are unambitious and without any architectural or constructional enthusiasm (Kalčič, 2001). Larger architectural studios also published special catalogues with several conceptual plans, separated after regional styles of SFRY (Naš stan, 1979). Some of those plans were almost absurd, (Fig. 5) but architectural plans and building documentation were in that case almost free. Designing plans and architecture was still the domain of architects, but construction was the domain of self-managed construction. That this approach was especially popular in the SFRY, is confirmed by the statement, that a self-managed construction is still valid after the Slovenian Construction Act in paragraph 79 (UL RS 102/04, 14/05, ZJC-B, 93/05 - ZVMS, 111/05 - odl. US, 126/07, 108/09, 61/10 - ZRud-1, 20/11 - odl. US, 57/12, 101/13 - ZDavNepr, 110/13 in 19/15). 


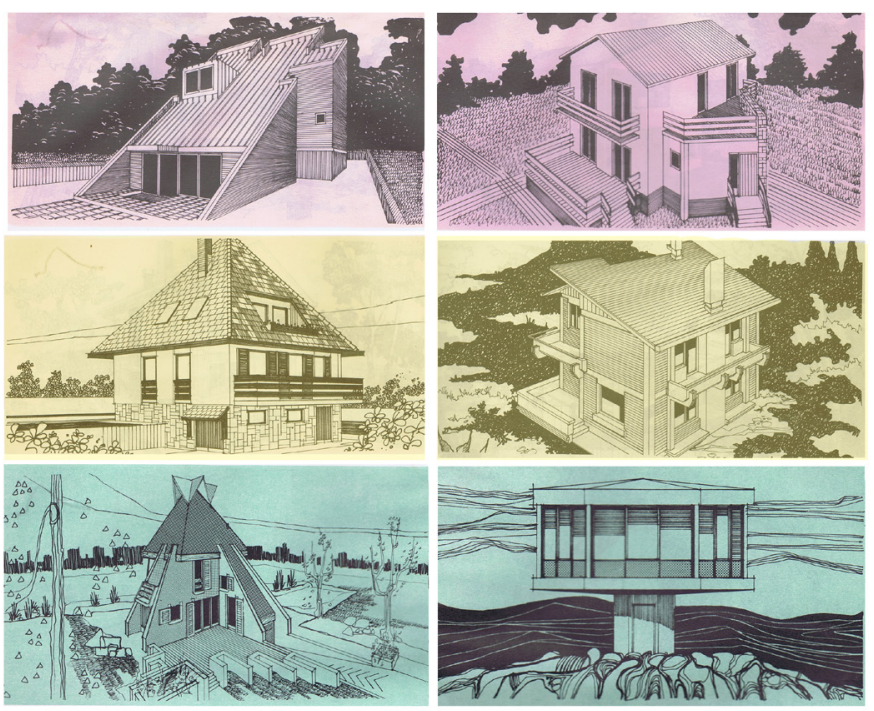

Fig. 5 Some examples gathered from the Catalogue of type projects, Naš stan Beograd (produced by the architectural bureau in 1979). In the figure, we can see several different types of type projects from the catalogues. The issue is that they followed different architectural styles including modern ones; however, these architectural approaches do not integrate into all (different) architectural landscapes (author of collage: Andreja Benko).

Next attempt of design simplification was set with aforementioned Slovenian Construction act (UL RS 102/04, 14/05, ZJC-B, 93/05 - ZVMS, 111/05 - odl. US, 126/07, 108/09, 61/10 - ZRud-1, 20/11 - odl. US, 57/12, 101/13 - ZDavNepr, $110 / 13$ in 19/15). This act allows for other engineers to design buildings, including those professions not necessarily related to architectural design. Slovenia unlike other countries (for example Germany and Austria), does not prescribe by law that the owner of an architectural studio has to be an architect. Consequently, the problem lies in current spatial legislation, as Slovenia as a young country still does not have a long legacy of legislation. As previously mentioned, the area of Slovenia belonged for several centuries to other countries, and the legislation changed accordingly. In that, we see a problem because the legislation did not evolve, but changed in entirety, depending on which country the area of Slovenia belonged.

In the time of SFRY, the interval we named as the period of mass residential construction, investors ordered building documentation, but constructors did not build in accordance with architectural plans. In the construction phase, they changed the buildings according to the wishes of investors or their "better" solutions. In time, this led to the problem of illegal and inconsistent objects that in reality differed from the objects the building permit was issued for. This problem is topical even today, and it creates its own chain reaction. This reduced the architects' role in the eyes of the investor and created the belief that it is "better to build your house on your own". (Fig. 6)

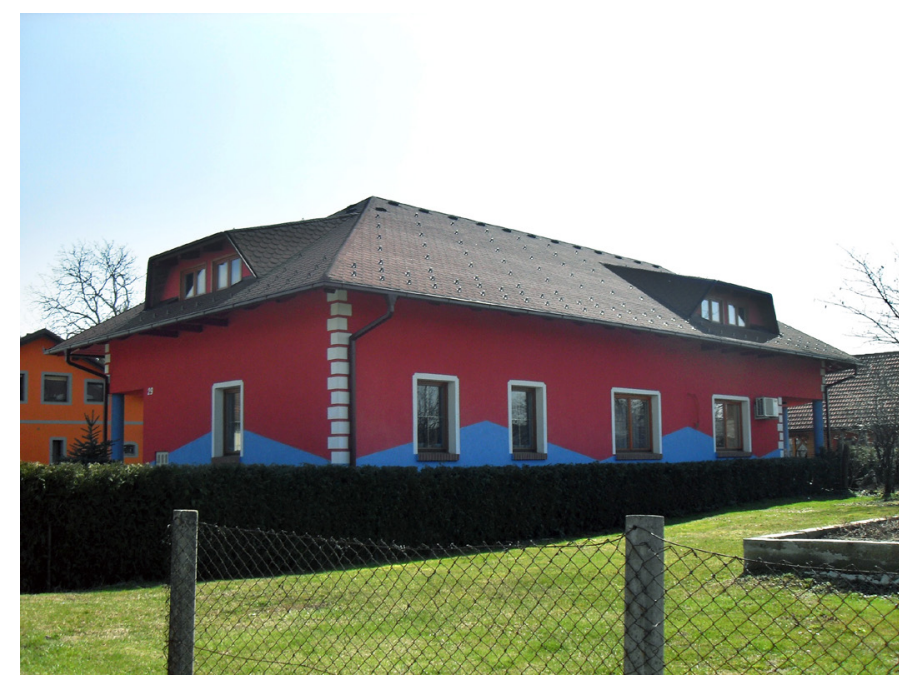

Fig. 6 Unprofessional intervention in the façade, which is disruptive for the surroundings, the architectural landscape and as well for neighbours. This kind of interventions in the architectural landscape clearly demonstrates the real need for architects' professional work (author: Andreja Benko).

\subsection{Architects' position during this period}

Respect for the profession fell during the considered period, with the consequence of the collapse of the traditional architectural landscape in Slovenia. The quality of architectural interventions into the architectural landscape was generally poor. It still holds true that at the beginning of the $20^{\text {th }}$ (until WW2) century, the architect was available only for the wealthier class, and has become, in the period of self-managed construction, the necessary evil that is needed to obtain building permits. This led to a lack of architectural (professional) supervision for designed objects (especially single-family houses). Also to absurd situations, when the constructors, in most cases without construction companies, unprofessionally interpret architectural plans, changing them to make construction easier. This can be ascribed to a lack of supervision (still a problem today), from an inspection service, although they did exist at that time. As per Rožman (2013), in the current time, we meet with a lack of responsibility towards the environment, disrespect and incomprehension of tradition and an ignorance of fundamental and other provisions of legislation. Subsequently, this period has left us with significant consequences, where architecture, together with architects must regain the respect, they deserve.

\section{Discussion}

Exposed problematics that are accompanied with problematic backgrounds (for example architectural and construction literacy of investors, the construction culture in Slovenia) are both interconnected and are complementary. As a result, solutions need to be comprehensive. 
The renovation of many partly inhabited single-family houses (about $50 \%$ ) from the time of mass construction is necessary. This provides an opportunity for economic possibilities and the living culture. Partly inhabited buildings also raise the social problematic, as they are too expensive to heat or maintain and are energetically poor. In 2008, the global economic crises influenced both the real-estate market and the construction sector (including architects). To improve the real-estate market, which fell from the 2008 high, and is currently static, the government established energy performance certificates that are necessary to sell a property. With this, they protected the buyer of a real estate but also raised the awareness of the important role of renewable energy sources and efficient energy use by the object. However, this is only partly a solution.

The discussed objects in quality locations deteriorated; while increasing numbers of young families searched for a flat or an advantageous loan for real estate. Hence, an opportunity and potential arises in the discussed buildings.

The Spatial Development Strategy of Slovenia (Strategy, 2004) stated that space is the public good of all citizens and that renovation has priority over new construction. A solution can be seen in the division of the object (horizontal or vertical), arranged into completely separated households. With this approach, it is possible to establish a "win-win" situation, easier maintenance and improved energetics (shared costs), and as well the social effect, for example, intergenerational companionship. Guidelines and conclusions from the Spatial Development Strategy of Slovenia (Strategy, 2004), should be more frequently considered in architectural praxis and spatial and construction legislation.

In the same way, it would also be possible to deal with the problem of inconsistent and illegal constructions, which has yet to be brought to a conclusion in Slovenia, although the profession is sounding many warnings. Inconsistent buildings are a consequence of the period of mass construction of singlefamily houses and poor inspection control at that time. Current Slovenian legislation still allows that kind of interventions, when dealing with the construction process, as for single-family houses, the habitation permit of the building is not necessary (Benko, 2015).

With a simpler or optimised approach by government departments for registration, and to keep a record of dwelling units over time, there would be less illegal or inconsistent building. This can be ensured by quality records of objects or residential units. Slovenia did carry out a survey; however, many mistakes were made during the process. We see an opportunity in the proper evidence or record of a started building site and by limiting the construction period. The Republic of Slovenia, especially the younger residents (young families), has to deal with a major housing problem - as they cannot get the credit to build, so they live and stay with their parents or grandparents. On the other hand, the referred to record of dwelling units produced by the government showed that in Slovenia, we have a considerable amount of property that is empty - no one uses them as they were bought as an investment.

The task of architects is to solve the current situation and to prevent similar mistakes in future. However, at first, it is important to raise the awareness of the general public of the role and importance of the architectural profession. The architect is not just a trustee of the environment; they are the link between the investor and/or user and governmental unit, and the professional for interventions into the environment and architectural landscape. The profession is one of several regulated professions in Europe, and it is key that it regains society's respect (UL RS 255/05, 2005). In the time of mass residential construction - since the 1960s, until today, the respect of the profession has fallen, largely because of the architects' relationship to planning and spatial interventions. The general economic crises from 2008 only deepen the situation. Slovenia's current legislation allows engineers from other professions to operate in the field of architecture; however, further changes are needed to ensure changes to spatial legislation and its novation, importantly also for general spatial documents, that are still missing in Slovenia (for example spatial politics, architectural and engineering act). Spatial legislation must first be adjusted to the professions' demands, which need to actively participate in different associations. Sadly, these changes often take too long and the efforts of many people; without them, individuals / companies take advantage of legislative mistakes or the lack of an incorrect interpretation; as a consequence, they are misused. After the Slovenian Construction Act (UL RS 102/04, 14/05, ZJC-B, 93/05 - ZVMS, 111/05 - odl. US, 126/07, 108/09, 61/10 - ZRud-1, 20/11 - odl. US, 57/12, 101/13 - ZDavNepr, $110 / 13$ in 19/15), an architect is often also the project designer; that is a legal or natural person that provides project design services as a commercial activity. Consequently, architects must be more active and participative in the process of legislation change. They need to give advice and suggestions to people who prepare the legislation as they come from praxis - field work and have the most experience.

The Construction Act also defines a responsible design manager - an architect with a valid license. The architect as a responsible design manager is responsible to the designer for the mutual compliance of all the designs that make up the project documentation and for the quality of the processing of the entire project. This responsibility is important; it is inadmissible that people, who have no experience with construction "lead" projects have the power to build the object without a valid building permit.

It is important to define individuals' responsibility in the construction procedure. Construction of the object is a joint procedure in three phases: design, construction and maintenance. Only 
with the specific definition of individuals' responsibility during construction, mutual collaboration between different engineering professions and of course greater control on the building site can we improve and manage the situation in future and regain the quality architectural landscape. Urban planning and architectural designing are necessarily multi-disciplinary processes. Architects and urbanists play a serious role, but the contribution of engineers, landscape architects, sociologists, economists, jurists, psychologists, historians and other technical experts is essential. A multi-disciplinary discourse between them is necessary, and architects have a responsible role in this process (Benkö, 2010).

Finally, it is essential to recover a respect for the architectural profession. For this, we must act and work mostly with the profession, by which we mean the architects. As previously referred to, it is necessary to educate the public about the important role the architect has in the construction procedure during all three phases. The architect is the professional that has the most experience with the design and construction of the object. Only with proper design and quality execution is it possible to create a quality object with less maintenance. This has a positive influence in the future. That the research on this theme was a step in the right direction we can confirm with a recent government decision; it decided in December 2015, that it will no longer be possible to construct self-domain objects. These works will, next year, require professional control/inspection, led by a professionally educated works leader.

\section{Conclusion}

In the conclusion, this paper summarizes the solutions to the issues, which were not only architectural but extended to different fields of spatial planning, spatial sociology, psychology, and legislation.

For the larger family houses, a change of building purpose - from a single-family house to two or more family objects is a way forward. With this solution, we can economically reduce expenses of the object and provide a more cost-effective and user-friendly result. At this point, legislation change would be necessary; this would ease the process and create optimal conditions for both governmental and construction changes.

It is necessary to emphasise the importance of reusing the discussed objects. The single-family houses represent the most common constructions in Slovenia. They have a tradition, and they still represent the most idyllic way of living for Slovenes. In this way, they represent an important influence on the architectural landscape. It is the architects' task, during their work and interventions during reconstructions or adaptations, to consider the issues referred to within this current review.

Motivating potential investors with several subventions and an approach to optimising the energy usage of households to avoid energetic poverty of Slovenes is also important. Some European funds have long been available, but the use of resources of by inhabitants is low. They need to be encouraged to use available resources and governmental units to help them with the necessary documentation are required.

The process of energy optimisation would have a broad positive effect on citizens, as would raising an awareness of national identity, common culture, and the lived architectural environment. Raising awareness and culture would in itself impact on the issues of improper and illegal building. Society has a desire for fascination, just for a moment, to want the next day more and more (Rožman, 2013). It is necessary, to bring architecture and spatial planning closer to the general public and potential investors. This is possible only by simultaneous and active education of the broader society. Investors need to be aware that different interventions are the domains of different professions, and that the architect is competent and responsible for spatial interventions. In this way, the problem of disloyal and unprofessional concurrence could be solved.

Education and architectural literacy have to embrace all age groups, starting with pre-school children. Only in this way can we expect a better relationship between inhabitants and the built environment, and to architecture and the profession.

\section{References}

Anon., n.d. Regulirani poklici. (Regulated jobs.) [Online]. Available from: http:// europa.eu/youreurope/citizens/work/professional-qualifications/regulatedprofessions/index_sl.htm [Accessed: January 2016] (in Slovene)

Benko, A. (2015) Odgovornosti projektanta, investitorja in uporabnika za skladnejše projektiranje enostanovanjskih stab. (Responsible architectural communication for the investors and for the end sers in residential architecture design.) AR Architecture, Research. Univerza v Ljubljani, Fakulteta za arhitekturo, Ljubljana. (in Slovene)

Benkő, M. (2010) The Role ob Urban renewal in architectural Education. In: Urban Renewal/1st International Conference of the Department of Urban Planning and Design and the Foundation for Urban Architecture. BME Urbanisztika Tanszek, Budapest, pp. 10-17.

Brezar, V. (1999) Stanovanjska arhitektura in zakonodaja. (Residential architecture and legislation.), Samozaložba, Ljubljana. (in Slovene)

Brojan, L. (2014) Potencial gradnje s slamo v Sloveniji. (Potencial of building with straw in Slovenia.), University of Ljubljana, Faculty of Architecture, Ljubljana. (in Slovene)

Fehérváry, K. (2011) The Materiality of the New Family House in Hungary: Postsocialist Fad or Middle-class Ideal? City and Society. 23(1), pp. 18-41. DOI: 10.1111/j.1548-744X.2011.01047.x

Kalčič, I. (2001) 11th Alpe Adria Ljudska arhitektura. [Online]. Available from: http://www2.arnes.si/ supbjuva/2001/kalc01/kalc01cs.html [Accessed: January 2016]

Kos, D. (2002) Praktična sociologija za načrtovalce in urejevalce prostora. (Practical Sociology for Designers and Landscape Designers.), University of Ljubljana, Faculty of Social Sciences, Ljubljana. (in Slovene)

Naš stan (1979) Katalog tipskih projekata, sa preko 1300 tipova. (Catalogue of type projects with more than 1300 types.), Biro za projektiranje, Beograd. (in Serbian)

Rebernik, D. (2002) Urbano-geografsko proučevanje blokovskih stanovanjskih sosesk kot element urbanističnega planiranja. (Urban-geographic study of block neighbourhoods as an element of spatial planning.) Delo. pp. 463-475. (in Slovene) 
Rožman, K. (2013) Barve v prostoru in prostorski zakonodaji. (The colors in space and spatial legislation.) In: Urbani izziv, Posebna izdaja 2013, October, pp. 29-35. (in Slovene)

Kanhäuser, G., Tomasella, P., Trstenjak, Ž., Wall, P., Winkler, G., Zupančič, D. (2011) Workers' neighbourhoods and workers' cities 1750-1950. Arbeitsgemeinschaft Alpen-Adria, Projektgruppe Historische Zentren, Maria Saal.

STAT (2015) Statistični urad Republike Slovenije. (Statistical office of Republic of Slovenia.) [Online]. Available from: http://www.stat.si/ StatWeb/pregled-podrocja?idp $=6 \&$ headerbar $=5$ [Accessed: January 2016] (in Slovene)
Strategy (2004) The Spatial Development Strategy of Slovenia, Ljubljana: s.n. UL RS 102/04 - uradno prečiščeno besedilo, 14/05 - popr., 92/05 - ZJC-B, 93/05 - ZVMS, 111/05 - odl. US, 126/07, 108/09, 61/10 - ZRud-1, 20/11 - odl. US, 57/12, 101/13 - ZDavNepr, 110/13 in 19/15, n.d. Zakon o graditvi objektov. [Online] Available from: http://www.pisrs.si/Pis.web/ pregledPredpisa?id=ZAKO3490 [Accessed: January 2016] (in Slovene)

UL RS 255/05, (2005) Uradni list. (Official Gazette.) [Online]. Available from: http://www.mizs.gov.si/si/storitve/izobrazevanje/priznavanje_poklicnih_kvalifikacij/ [Accessed: January 2016] (in Slovene) 